\title{
Evidence for the existence of a local activin-follistatin negative feedback loop in the goldfish pituitary and its regulation by activin and gonadal steroids
}

\author{
Gheorghe F Y Cheng, Chi-Wai Yuen and Wei Ge \\ Department of Biology, The Chinese University of Hong Kong, Shatin, New Territories, Hong Kong, China \\ (Correspondence should be addressed to W Ge; Email: weige@cuhk.edu.hk)
}

\begin{abstract}
Activin is an important regulator of gonadotropin expression and production in the vertebrate pituitary, and its activity is fine-tuned by its binding protein follistatin. In the present study, a full-length cDNA for follistatin was cloned in the goldfish, which shows $74 \%$ amino acid sequence identity with that of mammals. Recombinant goldfish follistatin expressed in the Chinese hamster ovary cells significantly blocked activin-induced F5-5 cell differentiation. Goldfish follistatin is expressed in a wide range of tissues including the brain, pituitary, ovary, and testis. The expression of follistatin mRNA in the pituitary is regulated by both activin and gonadal steroids in vitro. Treatment with goldfish activin B for $48 \mathrm{~h}$ significantly up-regulated follistatin expression in cultured pituitary cells, suggesting a closed activin-follistatin feedback loop in the pituitary. In agreement with this, both
\end{abstract}

human and goldfish follistatin down-regulated the expression of follistatin itself, probably due to the neutralization of endogenous activin. Examination of FSH $\beta$ and LH $\beta$ expression in the same samples supports the role of activin and follistatin in the differential regulation of FSH and LH as demonstrated previously. Since the expression level of activin $\beta_{\mathrm{B}}$ in the pituitary is rather stable both in vitro and in vivo, it is conceivable that follistatin may play a pivotal regulatory role in the intra-pituitary activin system. Both estradiol and testosterone up-regulated follistatin expression in vitro, suggesting a mediating role for follistatin in steroid feedback on pituitary hormones. These results provide clues to the potential physiological roles of activin-follistatin system in the regulation of gonadotropin biosynthesis in teleosts.

Journal of Endocrinology (2007) 195, 373-384

\section{Introduction}

Gonadotropins, follicle-stimulating hormone (FSH) and luteinizing hormone ( $\mathrm{LH})$, are the primary hormones governing gonadal development and function in vertebrates including teleosts (Gharib et al. 1990, Swanson et al. 2003, Weltzien et al. 2004). Similar to those in mammals (Gharib et al. 1990, Burger et al. 2004), the secretion and expression of fish gonadotropins are controlled by both neuroendocrine factors from the hypothalamus such as gonadotropin-releasing hormone (GnRH; Peter et al. 1986, Weltzien et al. 2004, Ando \& Urano 2005) and steroids from the gonads (Kobayashi et al. 1987, 1989, Dickey \& Swanson 1998). Our previous study in the goldfish demonstrated that in addition to the neuroendocrine and endocrine regulation, pituitary gonadotropins are also subject to local paracrine regulation by activin (Yam et al. 1999a, Yuen \& Ge 2004), similar to the situation in mammals (Roberts et al. 1989, Corrigan et al. 1991, Bilezikjian et al. 2004).

Activin $\left(\beta_{A} \beta_{A}, \beta_{A} \beta_{B}\right.$, and $\left.\beta_{B} \beta_{B}\right)$ was first identified as an ovarian factor in mammals that specifically stimulated pituitary FSH secretion without any effect on LH (Ling et al.
1986, Vale et al. 1986). Its subunits $\beta_{\mathrm{A}}$ and/or $\beta_{\mathrm{B}}$ have later been demonstrated to be expressed in a variety of extragonadal tissues including the pituitary in both mammals and fishes (Meunier et al. 1988, Roberts et al. 1989, Lau \& Ge 2005), suggesting a wide range of biological activities at various sites. The functionality of the pituitary-derived activin in regulating mammalian $\mathrm{FSH}$ secretion has been demonstrated by immunoneutralization of activin both in vitro (Corrigan et al. 1991) and in vivo (DePaolo et al. 1992). The activities of activin are modulated or fine-tuned by its potent binding protein follistatin, which serves as a local modulator of activin activities in various tissues including the pituitary (Welt et al. 2002). In the goldfish, the treatment of cultured pituitary cells with follistatin caused a decrease in FSH $\beta$ but an increase in LH $\beta$ expression (Yuen \& Ge 2004), which were opposite to the effects of activin (Yam et al. 1999a, Yuen \& Ge 2004), suggesting an intra-pituitary activin-mediated autocrine/paracrine system in this species (Yuen \& Ge 2004).

The potent modulatory effect of follistatin on activin and their co-expression in the pituitary suggest that the pituitaryderived follistatin may represent a regulatory point subject to the influence by both neuroendocrine and endocrine inputs, 
which in turn influences gonadotropin biosynthesis by suppressing activin activities. This hypothesis is supported by several studies in mammalian models. In the rat, a pulsatile application of $\mathrm{GnRH}$ at high frequency inhibited FSH $\beta$ by stimulating pituitary follistatin, leading to a decreased activin activity (Kirk et al. 1994, Besecke et al. 1996). Follistatin expression was noted to precede that of FSH $\beta$ in the rat pituitary during its estrous cycle but dropped drastically when FSH expression reached the maximal level (Halvorson et al. 1994), suggesting that follistatin expression may also be influenced by gonadal sex steroids. The effects of sex steroids on follistatin have been evidenced by the observation that gonadectomy stimulated pituitary follistatin in both male and female adult rats (Kaiser \& Chin 1993). In support of this, treatment with testosterone suppressed follistatin expression in the rat pituitary in vitro (Bilezikjian et al. 1996). In contrast, the expression of follistatin in the pituitary of rhesus monkey was stimulated by in vitro testosterone treatment (Kawakami et al. 2002). This discrepancy may account for the difference in the post-gonadectomy increase of FSH $\beta$ expression and FSH secretion between the rats (2- to 3-fold; Gharib et al. 1987) and primates (40-fold; Attardi et al. 1992). Interestingly, activin has been reported to stimulate follistatin mRNA expression (Bilezikjian et al. 1996), synthesis (Farnworth et al. 1995), and release (Bilezikjian et al. 1993) from cultured pituitary cells, and the effects could be abolished by follistatin itself. These results point to the presence of a local regulatory feedback loop involving activin and follistatin in the pituitary (DePaolo et al. 1991), and this regulatory loop is subject to the regulation by external hormonal factors.

In the goldfish, both activin $\beta_{\mathrm{A}}$ and $\beta_{\mathrm{B}}$ have been cloned by our laboratory (Ge et al. 1997, Yam et al. 1999a), and our previous work has demonstrated that different from the situation in mammals, activin differentially stimulates goldfish FSH $\beta$ but suppresses LH $\beta$ expression, and its effects can be reversed by follistatin (Yam et al. 1999a, Yuen \& Ge 2004). The inverse effects of activin on the expression of the two gonadotropins make goldfish a unique model for studying the role of activin in the differential regulation of FSH and $\mathrm{LH}$. Similar to that in mammals, we have also shown that the transcript of activin $\beta_{\mathrm{B}}$ subunit, but less likely $\beta_{\mathrm{A}}$, is expressed in the goldfish pituitary (Ge et al. 1997, Yam et al. 1999b, Lau \& Ge 2005). This, together with the reports in mammals that follistatin is also expressed in the pituitary (Besecke et al. 1996, Bilezikjian et al. 1996), has led us to hypothesize that there may exist a local paracrine regulatory system involving activin and follistatin in the goldfish pituitary, and this system may serve as a regulatory point that relays various neuroendocrine and endocrine inputs to the pituitary to control pituitary hormone biosynthesis, especially that of gonadotropins. In support of this hypothesis would be the evidence for activin and follistatin response to potential factors that control pituitary function. The present study was therefore undertaken to characterize the activin-follistatin system in the goldfish pituitary, with particular emphasis on its regulation.

\section{Materials and Methods}

\section{Experimental animal}

Goldfish (Carassius auratus) of about 4-5 inches in body length were purchased from the local pet market and reared in 10001 flow-through tanks with ample aeration for at least 1 week before use. The conditions for maintaining the fish were at $22{ }^{\circ} \mathrm{C}$ water temperature and $14 \mathrm{~h}$ light: $10 \mathrm{~h}$ darkness photoperiod. All experiments were performed under the license from the Government of the Hong Kong Special Administrative Region and endorsed by the Animal Experimentation Ethics Committee of the Chinese University of Hong Kong. All fishes were anesthetized with tricaine methanesulfonate (MS222) before killing.

\section{Reagents}

Chemicals and enzymes were purchased from Sigma and Promega respectively unless otherwise specified. The medium M199 used in cell culture was obtained from Gibco Invitrogen. The Flp-In CHO cells for recombinant goldfish follistatin production were purchased from Invitrogen. Recombinant human follistatin was kindly provided by Dr A F Parlow (National Hormone and Peptide Program, National Institute of Diabetes \& Digestive \& Kidney Disease, CA, USA). Recombinant goldfish activin B was produced in our laboratory from an established $\mathrm{CHO}$ cell line, and one unit $(\mathrm{U})$ is defined as the amount per $\mathrm{ml}$ that induces half maximal erythroid differentiation of F5-5 cells $\left(\mathrm{ED}_{50}\right)$. Estradiol $\left(\mathrm{E}_{2}\right)$ and testosterone $(\mathrm{T})$ were purchased from Sigma. All drugs were first prepared as stocks and then diluted to specific working concentrations in culture medium before use.

\section{Extraction of total RNA and reverse transcription}

Goldfish tissues were collected and the total RNA from each tissue $(10-30 \mathrm{mg})$ extracted in a $1.5 \mathrm{ml}$ microtube containing $200 \mu \mathrm{l}$ TRI Reagent (Molecular Research Center, Cincinnati, OH, USA) according to the manufacturer's protocol with some modifications. Following homogenization of the tissue, chloroform $(50 \mu \mathrm{l})$ was added to each microtube, vortexed, and left at room temperature for $15 \mathrm{~min}$. After centrifugation at $4{ }^{\circ} \mathrm{C}$ for $20 \mathrm{~min}$, the aqueous supernatant was transferred to another tube containing $100 \mu$ isopropanol for precipitation $\left(-20^{\circ} \mathrm{C}, 10 \mathrm{~min}\right)$. The pellet was washed with 75\% ethanol prepared with diethylpyrocarbonate (DEPC)-treated water and dissolved in $4 \mu \mathrm{l}$ RNase-free water. For RNA extraction from single pituitary, the same procedure was followed after the pituitary was homogenized in $200 \mu \mathrm{l}$ TRI Reagent. The RNA $(1 \mu \mathrm{g})$ was then subjected to reverse transcription in a total volume of $10 \mu$ containing $1 \times$ Moloney murine leukemia virus (MMLV) first-strand buffer, $0.5 \mathrm{mM}$ each dNTP, $0.5 \mu \mathrm{g}$ oligo-dT, and $100 \mathrm{U}$ MMLV reverse transcriptase (Promega) at $42{ }^{\circ} \mathrm{C}$ for $2 \mathrm{~h}$. 
Cloning and sequencing of full-length $c D N A$ encoding goldfish follistatin

A pair of degenerate primers (Primer 1 and Primer 2; Table 1) was designed based on the conserved amino acid sequences of follistatin from other species. A goldfish ovarian cDNA library was used as template for PCR amplification, which was performed in $1 \times$ PCR buffer, $0.2 \mathrm{mM}$ each $\mathrm{dNTP}$, $2.5 \mathrm{mM} \mathrm{MgCl}_{2}, 0.6 \mathrm{U}$ Taq polymerase, and $0.2 \mu \mathrm{M}$ each primer in a total reaction volume of $25 \mu$. The reaction was run for 31 cycles with the profile of $30 \mathrm{~s}$ at $94{ }^{\circ} \mathrm{C}, 30 \mathrm{~s}$ at $56{ }^{\circ} \mathrm{C}$, and $1 \mathrm{~min}$ at $72{ }^{\circ} \mathrm{C}$.

The fragment amplified from goldfish ovary was purified and cloned into pBluescript II KS $(+)$ (Stratagene, La Jolla, CA, USA) by T/A cloning and sequenced. An antisense gene-specific primer (Primer 3; Table 1) was then designed to amplify the $5^{\prime}$-region of the cDNA from the goldfish brain using SMART RACE cDNA Amplification Kit (Clontech Laboratories). The RACE PCR was performed according to the manufacturer's instructions. The amplified $5^{\prime}$-cDNA end was cloned as described above and sequenced. A sense genespecific primer (Primer 4; Table 1) was then designed based on the $5^{\prime}$-end sequence of the cloned $5^{\prime}$-RACE product to amplify and clone the full-length cDNA by $3^{\prime}$-RACE.

The sequences of both strands of the cloned cDNA were obtained by exonuclease III and mung bean nuclease deletion method. All the sequencing reactions were performed on Peltier Thermal Cycler 100 (MJ Research, San Francisco, CA, USA) using dRhodamine Terminator Cycle Sequencing Ready Reaction Kit (Perkin-Elmer, Foster City, CA, USA). The sequence was analyzed by ABI PRISM 310 Genetic Analyzer (Perkin-Elmer) followed by GenBank database search.

\section{Production of recombinant goldfish follistatin}

The Flp-In CHO Expression System (Invitrogen) was used to produce recombinant goldfish follistatin. Briefly, a pair of primers (Primer 5 and Primer 6; Table 1) was designed based on the sequence of the cloned cDNA, which flank the open reading frame (ORF) of goldfish follistatin. Two restriction sites, HindIII and BamHI, were added to the two primers respectively for cloning into the expression vector, pcDNA/ FRT. A Kozak sequence (CCACC) was included between HindIII and the initiation codon ATG to improve translation efficiency (Kozak 1984). The protocol used for amplifying ORF was the same as described above except that Pfu polymerase $(1.5 \mathrm{U})$ instead of $\mathrm{Taq}$ was used to increase fidelity of the reaction. The purified amplicon was digested with HindIII and BamHI and subcloned into the double-digested pcDNA/FRT to obtain the expression construct pcDNA/ FRT/goldfish follistatin (gfFS). To facilitate future purification of recombinant follistatin, we also constructed an expression plasmid that contained an insert with six His residues added at the carboxyl terminal (pcDNA/FRT/gfFSHis). The construction of pcDNA/FRT/gfFS-His was the same as that of pcDNA/FRT/gfFS except that the antisense primer had the codons for His residues incorporated.

The cultured Flp-In CHO cells at $\sim 40 \%$ confluence were co-transfected with pcDNA/FRT/gfFS or pcDNA/FRT/gfFSHis and pOG44 at the ratio of 1:9 by Lipofectamine (Invitrogen). The plasmid pOG44 provides the recombinase essential for genomic integration. The transfected cells were cultured to confluence in Ham F12 medium containing $100 \mathrm{U} / \mathrm{ml}$ penicillin, $100 \mu \mathrm{g} / \mathrm{ml}$ streptomycin, and $10 \%$ fetal calf serum (HyClone Laboratories, Logan, UT, USA) at $37^{\circ} \mathrm{C}$ with $5 \%$ $\mathrm{CO}_{2}$. The cells were then trypsinized, washed, and plated in $10 \mathrm{~cm}$ culture dishes at the density of $1 \times 10^{4} / \mathrm{ml}$ for selection with $450 \mathrm{ng} / \mathrm{ml}$ hygromycin B (Invitrogen). Individual clones were isolated by limited dilution in 96-well plates. The positive clones were identified by PCR on the genomic DNA and RT-PCR on the total RNA isolated from each clone.

\section{Functional assay for recombinant goldfish follistatin}

The biological activity of recombinant goldfish follistatin was assessed based on its inhibition of activin-induced differentiation of F5-5 cells, a mouse erythroleukemia cell line that responds to activin by differentiating into hemoglobinproducing cells (Eto et al. 1987, Schwall \& Lai 1991). The assay protocol was according to Machida et al. (2000) with some modifications. Briefly, the F5-5 cells were cultured at $37^{\circ} \mathrm{C}$ with $5 \% \mathrm{CO}_{2}$ in Ham F12 medium containing $100 \mathrm{U} / \mathrm{ml}$ penicillin, $100 \mu \mathrm{g} / \mathrm{ml}$ streptomycin, and $10 \%$ fetal calf serum (HyClone Laboratories). The cells were plated at a density of 2000 cells $/ 400 \mu \mathrm{l} /$ well in a 48 -well plate. Hemoglobin production reached maximal level after incubation for 6 days with recombinant goldfish activin $\mathrm{B}$. To assay the activity of follistatin produced, the conditioned media collected from

Table 1 Primers used in cloning goldfish follistatin and constructing pcDNA/Flp/rgFS

Use

Strand

No.

1
2
3
4
5
6

www.endocrinology-journals.org

$\begin{array}{ll}\text { Degenerate PCR } & \text { Sense } \\ & \text { Antisense } \\ \text { 5'-RACE } & \text { Antisense } \\ \text { 3'-RACE } & \text { Sense } \\ \text { Recombinant expression } & \text { Sense } \\ & \text { Antisense }\end{array}$

Sequence

GAIGAIGAIGTICCIAA

TCIGGIGCICAIACICA

CGCAGACGCAGCGAGGCTTACTCCT

GGTTCATTCAGCACTGCCTGAGTA

CCCAAGCTTCCACCATGCAAAGGATGCTAAAGC CGCGGATCCTTACTTACAGTTGCAAGATCCTG' 
untransfected and transfected $\mathrm{CHO}$ cells as well as individual clones at $80 \%$ confluence were added to the culture wells in the presence or absence of activin $\mathrm{B}(3 \mathrm{U} / \mathrm{ml})$. Recombinant human follistatin was used as the positive control. After incubation for 6 days, the cells from each well were suspended, transferred to a $1.5 \mathrm{ml}$ microtube, and stained by $\mathrm{O}$-dianisidine/ $\mathrm{H}_{2} \mathrm{O}_{2}$ solution for $15 \mathrm{~min}$. After centrifugation to remove the supernatant, the pelleted cells were lysed with $100 \mu \mathrm{l} \mathrm{H}_{2} \mathrm{O}$ followed by freezing at $-80^{\circ} \mathrm{C}$ for $1 \mathrm{~h}$ and further solubilized with $10 \% \mathrm{SDS}$ at $37^{\circ} \mathrm{C}$ for $30 \mathrm{~min}$. The lysates were transferred to a 96-well plate and the absorbance at the wavelength of $405 \mathrm{nM}$ was measured on SpectraMax 250 microplate spectrophotometer (GMI Inc., Albertville, MI, USA).

\section{Primary culture of dispersed pituitary cells}

The primary culture of goldfish pituitary cells was performed as described previously (Yam et al. 1999a). Briefly, the pituitaries were collected from both males and females, washed, minced into small pieces, and trypsinized to disperse the cells. The dispersed cells were seeded in 48-well plates at a density of $0 \cdot 4-0 \cdot 6 \times 10^{6}$ cells $/ 0.5 \mathrm{ml} /$ well in $70 \%$ M199 supplemented with Earle's salt and $10 \%$ fetal calf serum (Hyclone Laboratories) and incubated at $28{ }^{\circ} \mathrm{C}$ with $5 \% \mathrm{CO}_{2}$. The plates were pre-coated with $0 \cdot 01 \%$ poly-D-lysine to enhance cell attachment. After pre-incubation for $24 \mathrm{~h}$, the medium was changed before drug treatment.

\section{Real-time RT-PCR assays}

Total RNA from the cultured pituitary cells or individual pituitary gland was extracted with Tri Reagent and reverse transcribed as described above. The levels of gene expression were assayed with real-time RT-PCR. All primers used in the assays are listed in Table 2. To prepare standard for real-time

Table 2 Primers used in real-time PCR assays

\begin{tabular}{|c|c|c|c|}
\hline \multirow[b]{2}{*}{ No. } & Gene & Strand & Sequence \\
\hline & & & \\
\hline 7 & $\begin{array}{l}\beta \text {-actin } \\
\quad \text { (bactin) }\end{array}$ & Sense & TGCGGAATATCATCTGCCTGTA \\
\hline 8 & & Antisense & CAACAACCAGTGCGGCAAT \\
\hline 9 & $\begin{array}{l}\text { Follistatin } \\
(f s t)\end{array}$ & Sense & CCACGTGCTTGCTTGGTAGA \\
\hline 10 & & Antisense & CCACGCTGCAATGGATATCA \\
\hline 11 & $\begin{array}{c}\text { Activin } \beta_{\mathrm{B}} \\
\quad(\text { inh } b b)\end{array}$ & Sense & GACAAGACCTCGACATTCACTG \\
\hline 12 & & Antisense & CAGGAATGGACGGTGTGAGG \\
\hline 13 & $\begin{array}{l}\text { FSH } \beta \\
\quad(f s h b)\end{array}$ & Sense & GCAAGTGTAACTCTGACATCACAG \\
\hline 14 & & Antisense & GTTTCСTTGTCTAATGTGCATTGC \\
\hline 15 & $\mathrm{LH} \beta(/ h b)$ & Sense & AGAGCCCАTTTTCСАСТGTCTAC \\
\hline 16 & & Antisense & GAGAGCCACAGGGTAGGTGAT \\
\hline 17 & $\mathrm{GH}(g h)$ & Sense & TACCCCAGCCAGACСCTGAG \\
\hline 18 & & Antisense & CCATCGAGACTTCССТTAATGAGC \\
\hline
\end{tabular}

PCR assay, the cDNA fragment of each target gene was amplified and purified by phenol/chloroform extraction and ethanol precipitation. The amplicon was then quantified by electrophoresis on a $1 \cdot 8 \%$ agarose gel together with serially diluted MassRuler DNA Marker (MBI Fermentas, Hanover, MD, USA). The analysis and quantification were carried out on the Gel-Doc 1000 system with Molecular Analyst software (Bio-Rad).

The real-time PCR assay was performed on the iCycler iQ Real-time PCR Detection System (Bio-Rad) in a volume of $30 \mu \mathrm{l}$ containing varying amounts of RT reaction product, $1 \times$ PCR buffer, $0.2 \mathrm{mM}$ each dNTP, $2.5 \mathrm{mM} \mathrm{MgCl}$, $0 \cdot 2 \mu \mathrm{M}$ each primer, $0 \cdot 75 \mathrm{U}$ Taq polymerase, SYBR Green I (1:35 000, Molecular Probes, Leiden, The Netherlands), and $20 \mathrm{nM}$ fluorescein (Bio-Rad). The PCR profile consisted of an initial denaturation at $95^{\circ} \mathrm{C}$ for $2 \mathrm{~min}$, followed by 40 cycles of denaturation for $20 \mathrm{~s}$, annealing at $56^{\circ} \mathrm{C}$ for $30 \mathrm{~s}$, and elongation at $72{ }^{\circ} \mathrm{C}$ for $30 \mathrm{~s}$. An extra step $\left(80^{\circ} \mathrm{C}\right.$ for $\left.7 \mathrm{~s}\right)$ was inserted in each PCR cycle for signal detection. A meltcurve analysis was performed at the end of the reaction to assess assay specificity, which was also confirmed by electrophoresis. A standard curve was always included for monitoring assay quality and calculating the levels of gene expression in the samples.

\section{Data analysis}

Each experiment was repeated at least twice with each treatment performed in triplicate. Data of follistatin bioassays were expressed as absorbance at $\mathrm{OD}_{405}$ and analyzed with one-way ANOVA followed by Dunnett's test. For the experiments on gene expression, the expression levels of goldfish follistatin, activin $\beta_{\mathrm{B}}$, FSH $\beta, \mathrm{LH} \beta$, and growth hormone $(\mathrm{GH})$ were normalized to $\beta$-actin, the internal control for RNA loading. Statistical analysis was performed with one-way ANOVA followed by Dunnett's test or Student's $t$-test using Prism 4.0 on Macintosh (GraphPad, San Diego, CA, USA). The differences were considered significant at $P<0.05$ and very significant at $P<0.001$.

\section{Results}

\section{Cloning and sequence analysis of goldfish follistatin}

A full-length cDNA (1228 bp) encoding goldfish follistatin was cloned by RACE. ORF analysis reveals that the cloned cDNA encodes a precursor protein with 323 amino acid residues (Fig. 1). GenBank database search showed that the deduced amino acid sequence had the highest homology with zebrafish follistatin (accession number: NM_131037; Fig. 1). The cloned goldfish follistatin lacks 27 conserved amino acids at the carboxyl terminal, similar to that of Xenopus and zebrafish, which is similar to the form of FS288 but different from FS315 reported in birds and mammals. The secretory nature of goldfish follistatin was suggested by the presence of a potential signal peptide at the amino terminal of the protein, 


\begin{tabular}{|c|c|c|}
\hline & 1 & MQRMLKRQLLHSRMILLL-LWLCYLTEDQKVQAGNCWLQQGKNGRCQVLYMPGMSREECC \\
\hline zebrafish & & 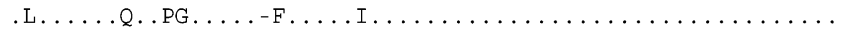 \\
\hline Xenopus & & -- . .N-ERIQPG . F. .TVS . HFM.YRA . . . . . . . . . . . . RTEL.K. . . \\
\hline hicken & & - - . . NQRIHPGML-V . - -MF. YHFM . .HTA. . . . . R. AR . . . . . KTDL. K . . . \\
\hline bovine & & -- . ARPRHQPGGLC . . - .L . QFM. .RSA . . . . . R.A. . . . . . KTEL.K. . . \\
\hline horse & & - - . VRPRHQPGGLC . . - .L . .QFM. .RSA . . . . . R.A. . . . . . KTEL.K. . . \\
\hline Duse & & - - . VCARHQPGGLC . . - .L. . QFM. .RSA . . . . . R. . . . . . . . KTEL.K. . . . \\
\hline human & & - - . VRARHQPGGLC . . . .L. . QFM. .RSA . . . . . R. A. . . . . . KTEL.K. . . \\
\hline & & $* \quad * * \quad * \quad * \quad * * * * * * * \quad * * * * * * * \quad * * * * *$ \\
\hline oldfish & 61 & RSGRLGTSWTEEDVANSTLFRWMIFNGGAPNCIPCKETCDNVDCGPGKKCKMNRRSKPRC \\
\hline zebrafish & & 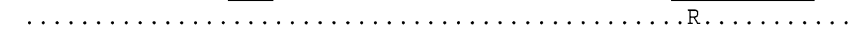 \\
\hline enopus & & 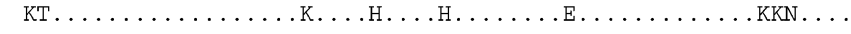 \\
\hline icken & & 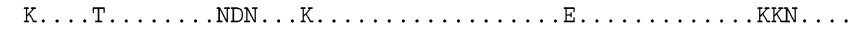 \\
\hline bovine & & 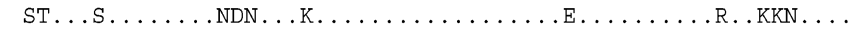 \\
\hline orse & & 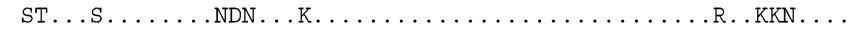 \\
\hline dse & & 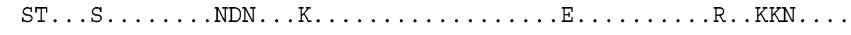 \\
\hline human & & 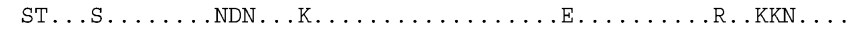 \\
\hline & & 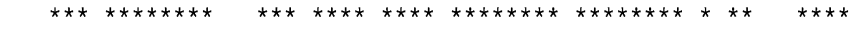 \\
\hline dfish & 121 & I VCAPDCSNITWKGSVCGSDGKTYRDECALLKSKCKGHPDLEVQYQGKCKKACHDVMCPGS \\
\hline ebrafish & & $\ldots \ldots \ldots$. $\ldots$ P. . . . . . . . . . \\
\hline pus & & 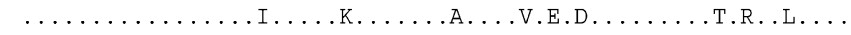 \\
\hline cken & & 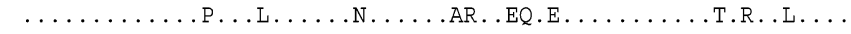 \\
\hline ovine & & 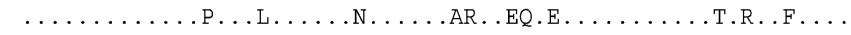 \\
\hline orse & & $\ldots \ldots \ldots \ldots$. . . . . . . N . . . AR . EQ.E. . . . . . . T.R. .N . . \\
\hline ase & & 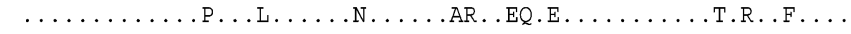 \\
\hline human & & 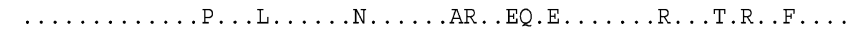 \\
\hline & & 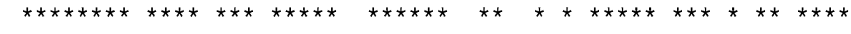 \\
\hline oldfish & 181 & I STCVVDQTNNAYCVTCNRICPEVTSPDSYLCGNDGIVYANACHLRRATCLLGRSIGVAYE \\
\hline zebrafish & & 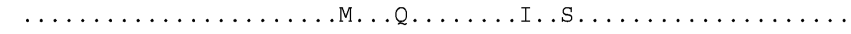 \\
\hline opus & & 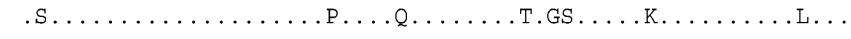 \\
\hline hicken & & 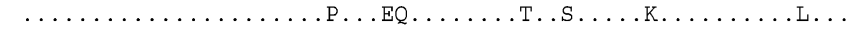 \\
\hline sovine & & $\ldots \ldots \ldots \ldots \ldots$. . SEQ . . . . VT.PS . . . K. . . . . . L . \\
\hline rse & & $\ldots \ldots \ldots \ldots \ldots$. . . . SEQ . . . . . VT.SS . . . K. . . . . . L . . \\
\hline buse & & $\ldots \ldots \ldots \ldots$. $\ldots \ldots$ PS.SEQ $\ldots \ldots$ VT.SS $\ldots \ldots$ K. . . . . L . . \\
\hline human & & $\ldots \ldots \ldots \ldots \ldots$. . . . . SEQ . . . . VT.SS . . . K. . . . . L . . \\
\hline & & 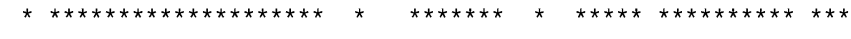 \\
\hline dfish & 241 & 1 GKCIKAKSCNDIHCSVGKKCLWDSKMGRGRCAVCMESCPESRSEEAVCASDNTTYPSECA \\
\hline rafish & & 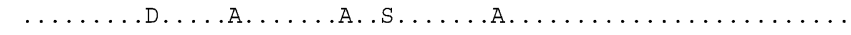 \\
\hline enopus & & 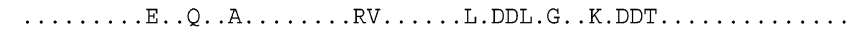 \\
\hline cken & & 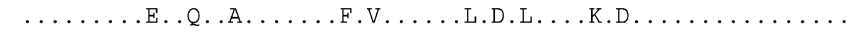 \\
\hline bovine & & 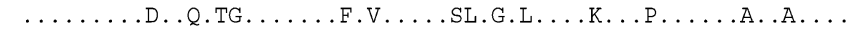 \\
\hline horse & & 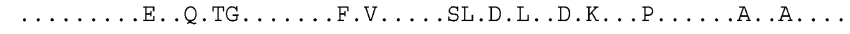 \\
\hline buse & & 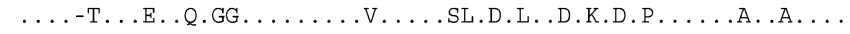 \\
\hline human & & $\ldots$. . . E. .Q.TG. . . . F.V. . . SL.D.L.D.K.D.P. . . . A. A. . \\
\hline & & 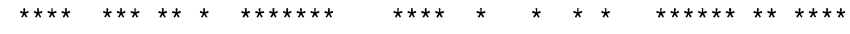 \\
\hline oldfish & 301 & MKQAACSLGVLLEVKHSGSCNCK- - - - - - - - - - - - - - - - - - \\
\hline brafish & & 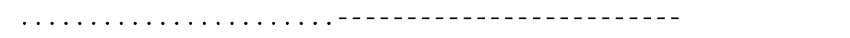 \\
\hline enopus & & … Т.І. . . . . . \\
\hline icken & & .................. . SINEDPEEEEEDEDQDYSFPISSILEW \\
\hline ovine & & ..................SISEDTEDEEEDEDQDYSFPISSILEW \\
\hline horse & & ..................SISEDTEEEEEDEDQDYSFPISSILEW \\
\hline buse & & ................. SISEETEEEEEEEDQDYSFPISSILEW \\
\hline גman & & . E. . ... . . . . . . . . SISEDTEEEEEDEDQDYSFPISSILEW \\
\hline
\end{tabular}

Figure 1 Deduced amino acid sequence of goldfish follistatin and its comparison with the homologous protein from representative species of amphibians, birds, and mammals. The potential signal peptide, lysine-rich heparan-binding site, and two predicted N-glycosylation sites (NST, NIT) are boxed. The asterisks $\left(^{*}\right)$ indicate sequence identity and the dashes $(-)$ represent the gaps inserted for better sequence alignment. 
which contains a leucine-rich hydrophobic region (ILLLLWLCYL) and a hydrophilic region (EDQKVQ) located just prior to the putative cleavage site $(\mathrm{A} / \mathrm{G})$. The possible cleavage site was identified between residues 33 and 34 , rendering the secreted mature peptide 290 amino acids.

Mature goldfish follistatin shows $75 \%$ of overall sequence identity with the molecule from other vertebrates (accession numbers: Xenopus, A53502; chicken, S55369; cow, I45894; horse, BAA25699; mouse, NP_032072; and human, AAH04107; Fig. 1). The arrangement of 36 cysteine residues (Shimasaki et al. 1988a), which is critical in determining the 3D structure of follistatin by forming intra-molecular disulfide bonds, is fully conserved among all vertebrate species compared. A potential lysine-rich binding site (KKCKMNRRSK) for heparan sulfate proteoglycan on target cells (Inouye et al. 1992, Sumitomo et al. 1995) is present at the 76th residue of the mature protein. Two potential $\mathrm{N}$-glycosylation sites are present at asparagines 43 (NST) and 92 (NIT) of the mature peptide, based on the consensus Asn-Xaa-Ser/Thr sequence, where Xaa can be any amino acid besides Pro and Asp (Walmsley \& Hooper 2003).

\section{Tissue distribution of follistatin expression in the goldfish}

To examine the expression of follistatin in the goldfish, primers specific for follistatin were designed based on the sequence of the cloned cDNA. As shown in Fig. 2, a specific band of expected size (432 bp) was detected in all the tissues of the brainpituitary-gonadal axis (brain, pituitary, ovary, and testis) although the expression level was relatively low in the pituitary. Expression offollistatin was also noted in the kidney and gill, but not in the liver. No product was observed in RT negative controls, which were the total RNA samples without being reverse transcribed. The expression of $\beta$-actin as the internal control could be detected in all the tissues tested.

\section{Functional analysis of recombinant goldfish follistatin}

After pcDNA/FRT/gfFS or pcDNA/FRT/gfFS-His was transfected into the Flp-In CHO cells, positive cells were selected and cloned in the presence of hygromycin $\mathrm{B}$. The production and functional identity of goldfish follistatin were examined by the inhibition of activin activity in the erythroid differentiation factor (EDF) bioassay using F5-5 cells. One of the clones (gfFS-C3) that exhibited the best performance in suppressing activin activity was identified and expanded. The conditioned medium from gfFS-C3 significantly suppressed the activin effect on F5-5 cells with an $\mathrm{ED}_{50}$ of about $1 \cdot 8 \mu \mathrm{l} / \mathrm{ml}$ (Fig. 3). As the positive control, recombinant human follistatin (FS288) also suppressed activin activity with an $\mathrm{ED}_{50}$ of about $3 \cdot 1 \mathrm{ng} / \mathrm{ml}$ (Fig. 3). The amount of recombinant goldfish follistatin in the medium collected after 2 -day incubation was therefore equivalent to $1.7 \mathrm{ng} / \mu \mathrm{l}$ human follistatin. Interestingly, addition of the His-tag at the carboxyl terminal appeared to abolish the activity of the recombinant protein because the selected pcDNA/FRT/
gfFS-His-transfected cells produced no bioactivity of suppressing activin although the mRNA was abundantly transcribed from the insert (data not shown).

\section{Activin regulation of follistatin expression in the pituitary}

Follistatin is a potent activin-binding protein and its expression has been demonstrated to be regulated by activin in a few systems (Farnworth et al. 1995, Dalkin et al. 1996, Besecke et al. 1996, Bilezikjian et al. 1996). To examine whether activin has any influence on the expression offollistatin in the goldfish pituitary, the cultured pituitary cells were exposed to different concentrations of goldfish activin B for $48 \mathrm{~h}$ after 24-h pre-incubation as described previously (Yuen \& Ge 2004). Activin B significantly stimulated the expression of follistatin in a dosedependent manner, and this effect could be blocked by co-incubation with recombinant human follistatin (Fig. 4A). Furthermore, treatment with human follistatin alone at $100 \mathrm{ng} / \mathrm{ml}$ nearly abolished the basal expression of goldfish follistatin in cultured pituitary cells (Fig. 4A).

We also analyzed the expression responses of FSH $\beta$ and LH $\beta$ in the same samples. As shown in Fig. 4B, activin significantly up-regulated FSH $\beta$ but inhibited LH $\beta$ expression, while treatment with human follistatin resulted in opposite effects on the expression of the two gonadotropin subunits, consistent with our previous report (Yuen \& Ge 2004). The conditioned medium from gfFS-C3 cells (recombinant goldfish follistatin) and recombinant human follistatin showed the same effects on the expression of FSH $\beta$, LH $\beta$, and follistatin itself (Fig. 5).

Effects of sex steroids on activin and follistatin expression in the pituitary

The dispersed goldfish pituitary cells were treated with various doses of testosterone or $\mathrm{E}_{2}$ for $48 \mathrm{~h}$ after pre-incubation. Treatment with testosterone $(1-100 \mathrm{nM})$ stimulated pituitary follistatin expression in a dose-dependent manner with the maximal response observed at $100 \mathrm{nM}$. Similarly, $\mathrm{E}_{2}$ also stimulated follistatin expression. Interestingly, none of the steroids had any effect on the expression of activin $\beta_{\mathrm{B}}$ (Fig. 6A). We also examined the responses of FSH $\beta$ and LH $\beta$ expression to the steroids in the same samples. The expression of LH $\beta$ was significantly up-regulated by both testosterone and $\mathrm{E}_{2}$ with the maximal stimulation being observed at the highest concentration $(100 \mathrm{nM})$. However, the expression of FSH $\beta$ showed little response to either testosterone or $E_{2}$ (Fig. 6B).

Annual expression profiles of follistatin, activin $\beta_{B}, F S H \beta, L H \beta$ and $\mathrm{GH}$ in the pituitary

The results described above suggested that there existed an activin-follistatin system in the goldfish pituitary and that follistatin could be the point of the system that is subject to regulation by endocrine and paracrine inputs. To provide 


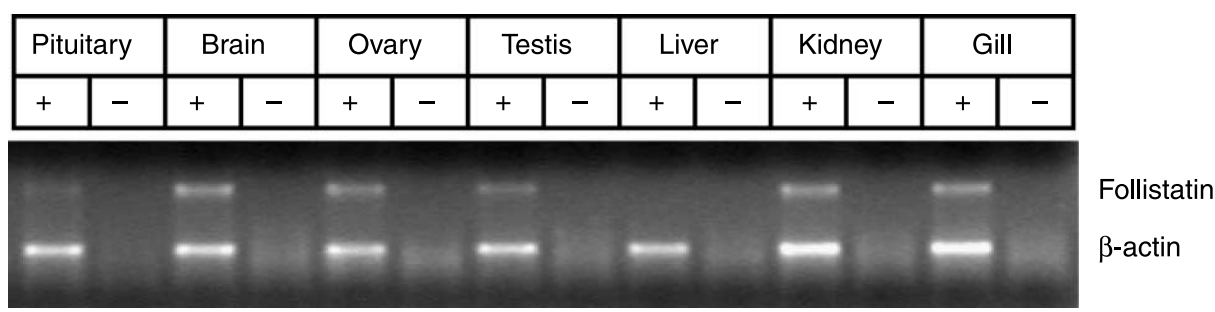

Figure 2 Tissue distribution of follistatin expression in the goldfish. Follistatin is expressed in all the tissues of the hypothalamic-pituitary-gonadal axis. +, reverse transcription with MMLV; - , reverse transcription without MMLV.

further evidence for this hypothesis, we examined the annual expression profiles of follistatin, activin $\beta_{\mathrm{B}}, \mathrm{FSH} \beta$, and $\mathrm{LH} \beta$ in the individual pituitary glands during a $12-$ month reproductive cycle. Since $\mathrm{GH}$ may have potential roles in vertebrate reproduction (Hull \& Harvey 2002), we also included GH in this study. In the spawning period (February and March), both FSH $\beta$ and $\mathrm{LH} \beta$ significantly increased their expression

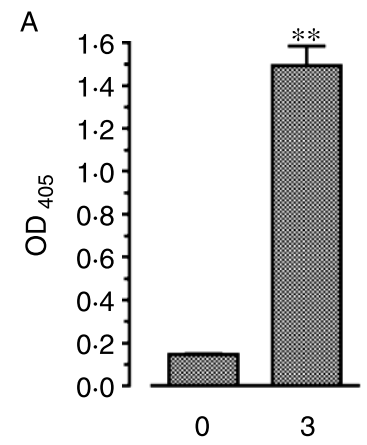

Activin B $(\mathrm{U} / \mathrm{ml})$

B

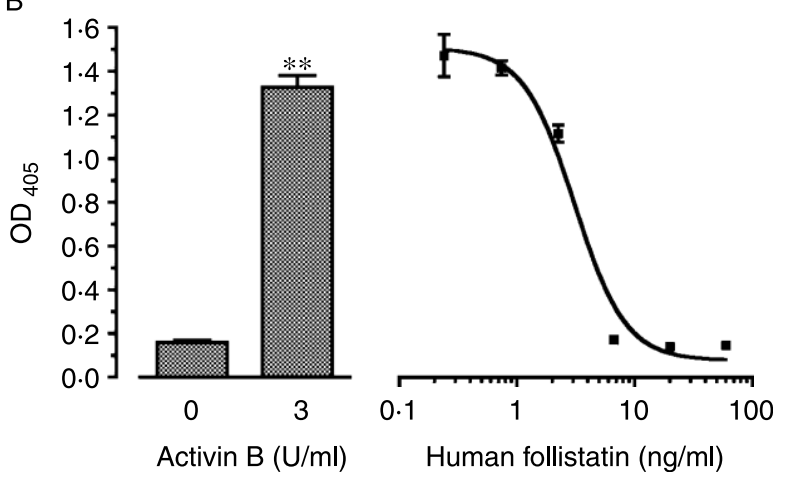

Figure 3 Detection of recombinant goldfish follistatin with EDF assay. The F5-5 cells were induced to differentiate into hemoglobinproducing cells by recombinant goldfish activin $\mathrm{B}(3 \mathrm{U} / \mathrm{ml})$. The differentiation was suppressed by the conditioned medium from rgFS-C3 (A) or recombinant human follistatin (B) in a dosedependent manner. The $\mathrm{ED}_{50}$ was estimated to be $3 \cdot 1 \mathrm{ng} / \mathrm{ml}$ and $1 \cdot 8 \mu \mathrm{l} / \mathrm{ml}$ for human follistatin and rgFS-C3 conditioned medium respectively. ${ }^{* *} P<0 \cdot 001$ versus control.
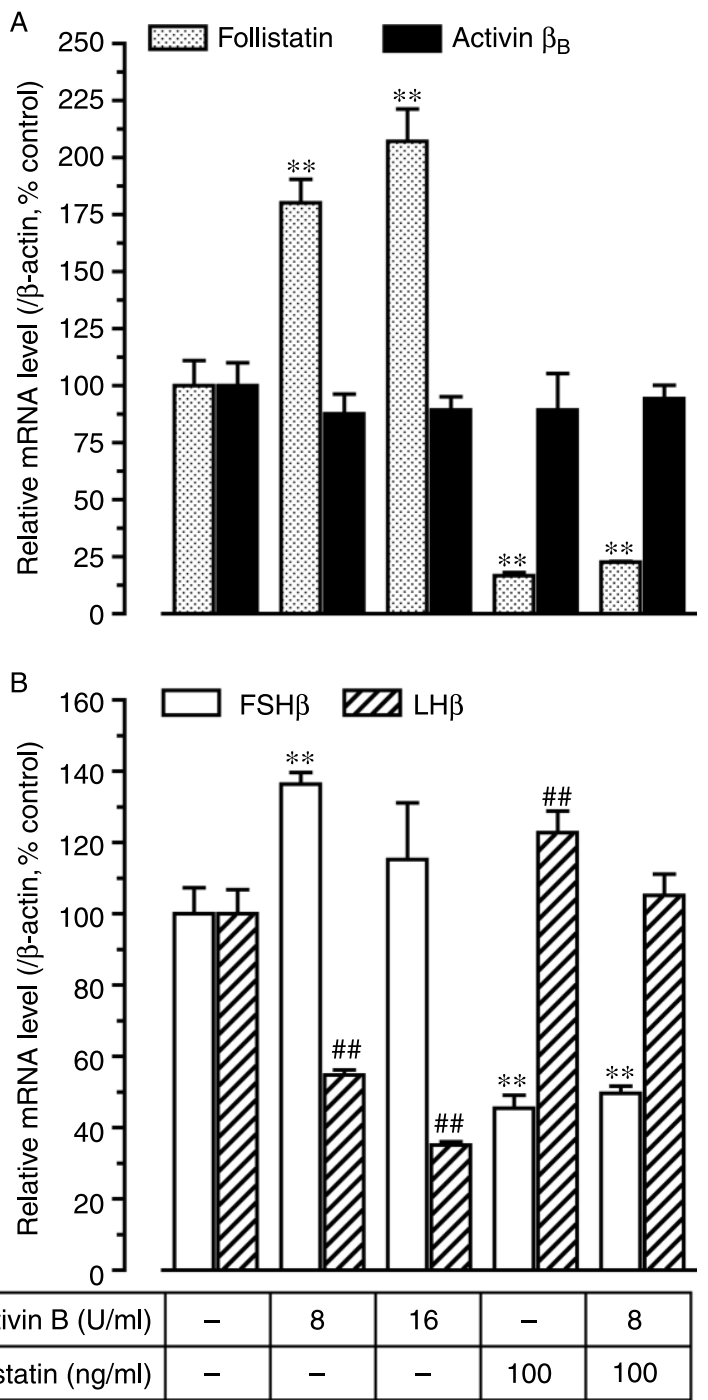

Figure 4 Effects of activin and follistatin on the expression of activin $\beta_{\mathrm{B}}($ inh $h b b)$, follistatin $\left(f_{s t}\right), \mathrm{FSH} \beta\left(f_{s} h b\right)$, and $\mathrm{LH} \beta(/ h b)$ in cultured goldfish pituitary cells. The cells were pre-incubated for $24 \mathrm{~h}$ followed by 48 -h treatment. The expression level of each gene was assayed by real-time RT-PCR and is expressed as the percentage of control (\% control) after normalization with $\beta$-actin (bactin). Each value represents the mean \pm S.E.M. of independent samples in four replicates. ${ }^{* *}{ }^{\# \# P} P<0 \cdot 001$ versus control. 
levels, which remained high in the post-spawning period (April and May). Their expression levels dropped abruptly in June and remained low in the seasons afterward. These profiles were similar to those reported previously in the same
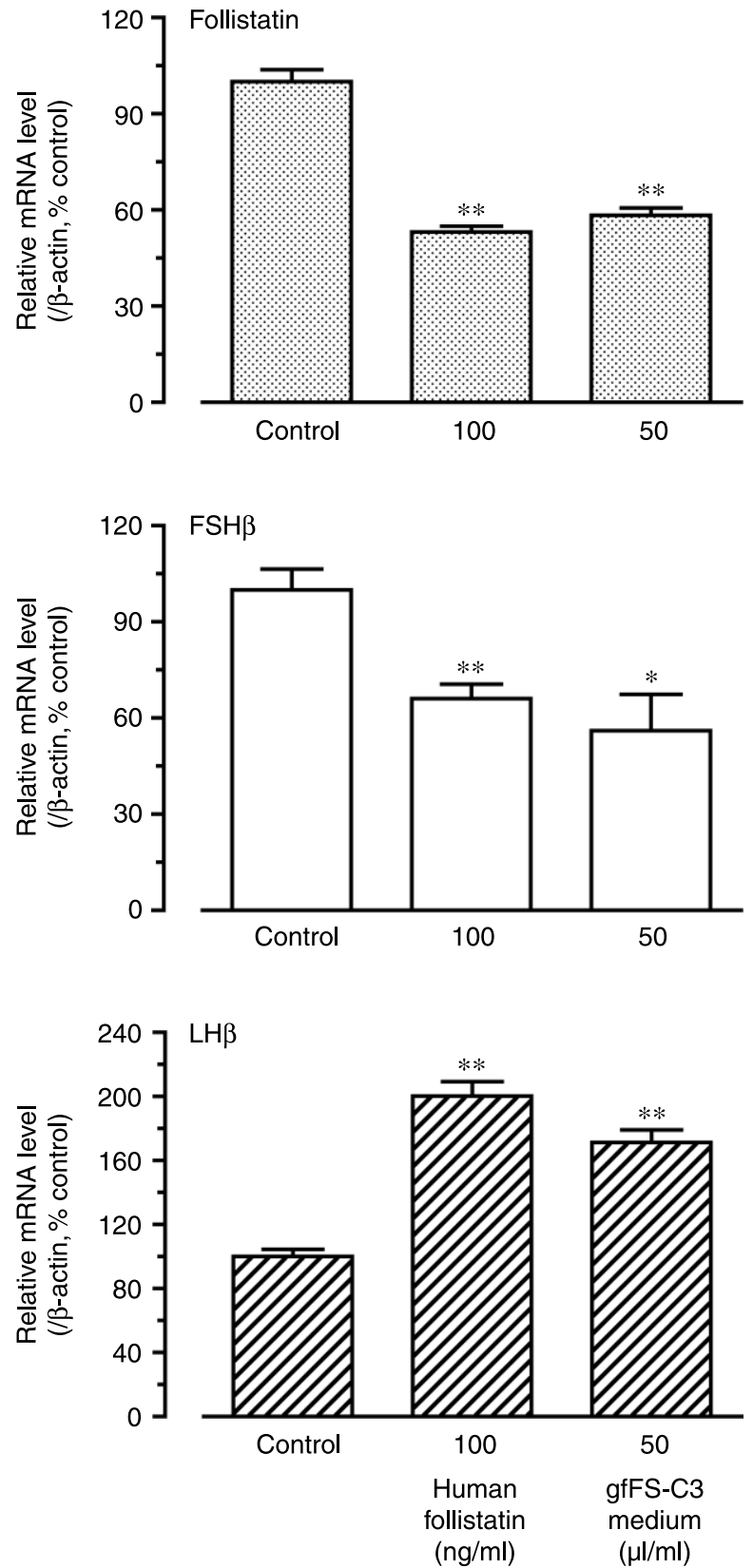

Figure 5 Effects of recombinant human follistatin $(100 \mathrm{ng} / \mathrm{ml})$ and recombinant goldfish follistatin $(50 \mu \mathrm{l} / \mathrm{ml})$ on the expression of follistatin, $\mathrm{FSH} \beta$, and $\mathrm{LH} \beta$ in the cultured pituitary cells. The cells were pre-incubated for $24 \mathrm{~h}$ before 48 -h treatment. The expression level is expressed as the percentage of control (\% control) after normalization with $\beta$-actin. Each value represents the mean \pm s.E.M. of independent samples in four replicates. ${ }^{*} P<0.05$ versus control; ${ }_{* *} P<0 \cdot 001$ versus control. species (Sohn et al. 1999). The GH showed relatively high expression levels in both the spring and autumn and low levels in the summer (June to August); however, the differences were not statistically significant. As demonstrated in vitro, the expression level of activin $\beta \mathrm{B}$ remained rather stable throughout the reproductive cycle with no significant trend of changes. In contrast, follistatin expression in the pituitary showed significant variation in the annual reproductive cycle with the highest levels detected from August to November (Fig. 7).

\section{Discussion}

A full-length cDNA encoding follistatin has been cloned from the goldfish using PCR and RACE approach. Goldfish follistatin exhibits as much as 95\% sequence identity with that of zebrafish (Bauer et al. 1998) and about $75 \%$ with the homologous protein of other vertebrates (Inouye et al. 1991, Tashiro et al. 1991, Connolly et al. 1995), suggesting conserved functions of this protein in vertebrates. In mammals and birds,
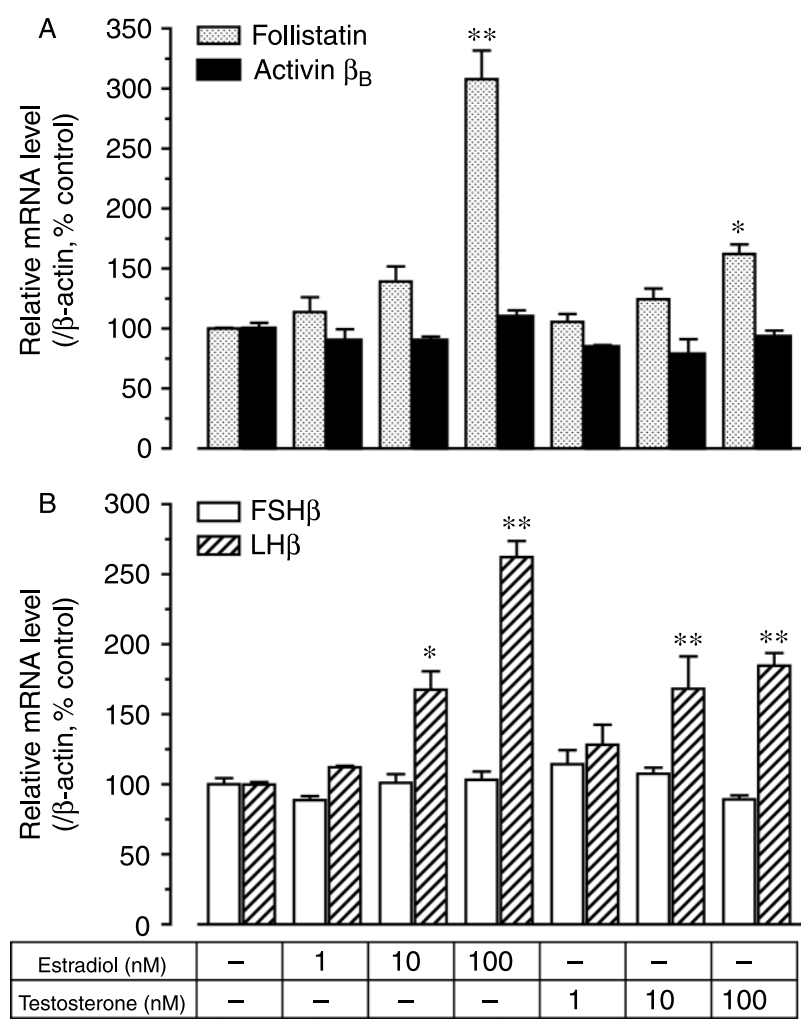

Figure 6 Effects of estradiol and testosterone on the expression of activin $\beta_{\mathrm{B}}$, follistatin, $\mathrm{FSH} \beta$, and $\mathrm{LH} \beta$ in cultured goldfish pituitary cells. The cells were pre-incubated for $24 \mathrm{~h}$ followed by $48-\mathrm{h}$ treatment. The expression level of each gene is expressed as the percentage of control (\% control) after normalization with $\beta$-actin. Each value represents the mean \pm S.E.M. of independent samples in four replicates. ${ }^{*} P<0 \cdot 05, * * P<0 \cdot 001$ versus control. 

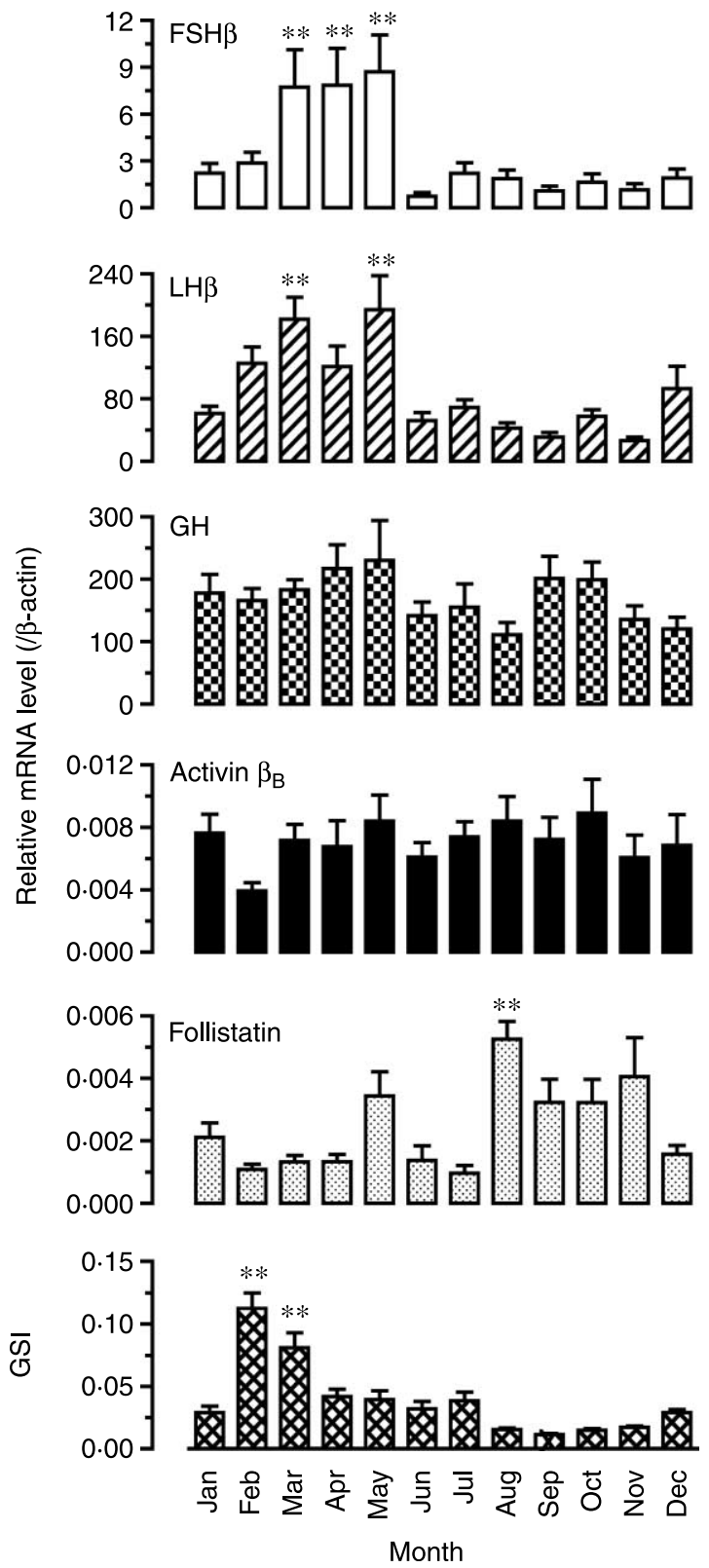

Figure 7 Seasonal expression profiles of pituitary FSH $\beta, \mathrm{LH} \beta, \mathrm{GH}$, activin $\beta_{\mathrm{B}}$, and follistatin in female goldfish. Pituitary glands were collected each month for real-time RT-PCR analysis. The expression levels were normalized with $\beta$-actin. The annual profile of gonadosomatic index (GSI) is shown at the bottom to indicate the ovarian stage of the fish sampled. Each value represents the mean \pm S.E.M. $(n=9-16) .{ }^{* *} P<0 \cdot 001$ versus January.

two differentially spliced forms of follistatin, FS315 and FS288, have been reported (Shimasaki et al. 1988a,b, Michel et al. 1990, Inouye et al. 1991), and the short form, FS288, which lacks 27 amino acids at the carboxyl terminus binds activin with 8-10 times higher potency than its full-length counterpart, FS315 (Inouye et al. 1991). The cloned goldfish follistatin also lacks these 27 amino acids at the carboxyl terminus compared with the form of FS315 in birds and mammals but possesses two extra amino acids (CK). We attempted to illustrate the presence of goldfish counterpart of FS315 using a pair of gene-specific primers designed at the carboxyl terminus flanking the location of the 27 residues; however, no specific product could be amplified (data not shown), which may suggest the lack of FS315 form in teleosts.

The functional identity of the cloned goldfish follistatin homolog was confirmed by establishing a stable $\mathrm{CHO}$ cell line (gfFS-C3) that expressed the protein. The conditioned medium from the cloned gfFS-C3 cells significantly suppressed activin-induced F5-5 cell differentiation, while the control $\mathrm{CHO}$ cells produced no follistatin activity (data not shown).

Although follistatin was first isolated from the follicular fluid (Esch et al. 1987, Robertson et al. 1987, Ueno et al. 1987), its expression has been shown in other locations of the brain-pituitary-gonadal axis as well as in a variety of nonreproductive tissues (Michel et al. 1990). RT-PCR analysis in the present study showed that goldfish follistatin also had widespread tissue distribution except for the liver, which correlates well with the ubiquitous expression of activin subunits in the goldfish (Lau \& Ge 2005). The co-expression of follistatin and activin in various tissues supports the idea that follistatin may be a critical factor in fine-tuning local activities of activin in the target tissues. It is noteworthy that although activin subunits and its receptors were detected in the goldfish liver in our previous studies (Ge et al. 1997, Yam et al. 1999b), the expression of follistatin was undetectable there, which agrees well with a previous study in the rat (Michel et al. 1990).

Similar to reports in mammals (Gospodarowicz \& Lau 1989, Kogawa et al. 1991), the present and our previous studies also demonstrated co-expression of activin and follistatin in the goldfish pituitary (Lau \& Ge 2005), suggesting an intra-pituitary activin-follistatin regulatory loop across vertebrates. Since activin stimulates goldfish FSH $\beta$ but inhibits LH $\beta$ expression in the goldfish (Yam et al. 1999a, Yuen \& Ge 2004), the co-expression of activin and follistatin in the pituitary has led us to hypothesize that the relative expression levels of FSH and LH are likely influenced by the balance between activin and follistatin in the pituitary, and any factors that disturb such balance would potentially regulate the expression of the two gonadotropins. An interesting question that follows would be how activin subunits and follistatin in the goldfish pituitary are regulated.

To address this question, we first investigated the effect of activin on follistatin expression in cultured goldfish pituitary cells. In agreement with our previous finding (Yam et al. 1999a), goldfish activin B exhibited differential effects on FSH $\beta$ and LH $\beta$ expression. In contrast, both human follistatin and the conditioned medium of gfFS-C3 cells that produced recombinant goldfish follistatin caused opposite responses of FSH $\beta$ and LH $\beta$, and these effects were likely due to the 
neutralization of endogenous activin in the pituitary. Interestingly, treatment with activin also significantly increased the expression of pituitary follistatin, therefore supporting the existence of a closed activin-follistatin regulatory loop in the pituitary (Fig. 8). The increased follistatin expression in response to activin may help keep the local activities of activin in check. In mammals, it has also been reported that addition of activin to cultured pituitary cells induced parallel increases of follistatin and FSH secretion in the rat (Bilezikjian et al. 1993) and sheep (Farnworth et al. 1995). The stimulatory effect of activin on follistatin has also been demonstrated at the transcriptional level (Besecke et al. 1996, Bilezikjian et al. 1996, Dalkin et al. 1996).

As a binding protein that modulates the activities of activin in various tissues, increasing evidence points to follistatin as a critical target of the activin-follistatin system that is subject to endocrine and neuroendocrine regulation. To test this hypothesis, we went on to examine the effects of gonadal steroids (testosterone and $\mathrm{E}_{2}$ ) on the expression of follistatin and activin $\beta_{\mathrm{B}}$, which is the main form of activin subunit expressed in the goldfish pituitary (Ge et al. 1997, Yam et al. 1999b, Lau \& Ge 2005). Both testosterone and $E_{2}$ significantly increased follistatin and $\mathrm{LH} \beta$ expression in cultured pituitary cells within the physiological range of concentration. However, neither testosterone nor $E_{2}$ had any effect on the expression of activin $\beta_{\mathrm{B}}$ and FSH $\beta$. Similar studies have also been performed in some

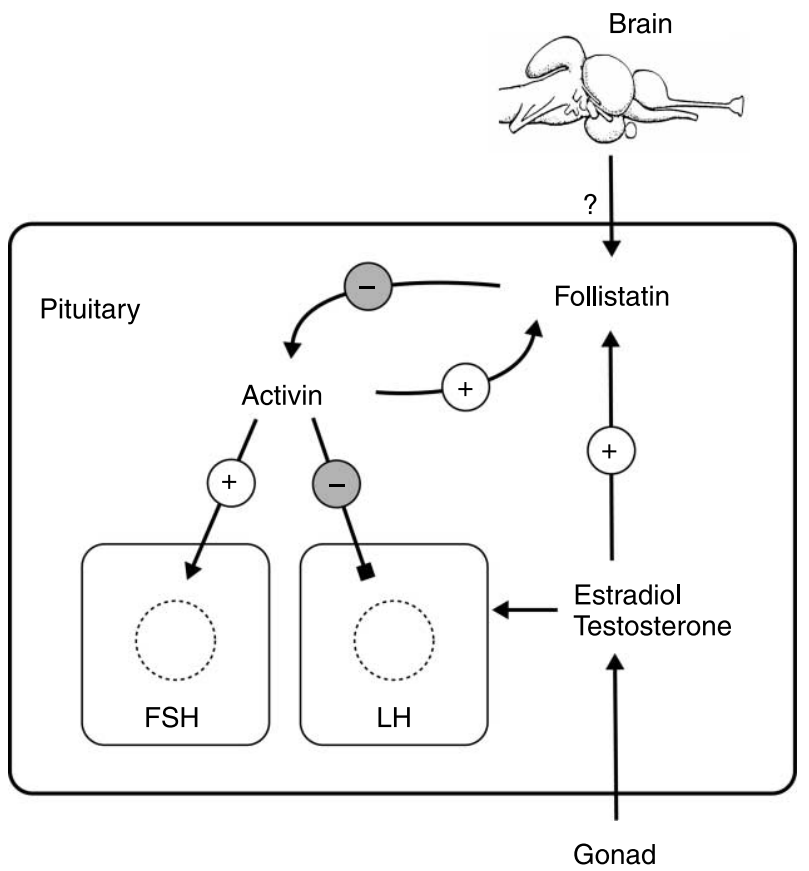

Figure 8 Hypothetical model for the role of follistatin in the goldfish pituitary. As an activin-binding protein that fluctuates during annual reproductive cycle and responds to both activin and gonadal steroids, follistatin is likely a critical regulatory point that receives and relays both neuroendocrine and endocrine inputs in the pituitary. Its level in turn fine-tunes the bioavailability of activin that influences multiple pituitary hormones including FSH and $\mathrm{LH}$. mammalian models, but the results have somehow been inconsistent. Testosterone treatment stimulated follistatin expression in the pituitary of rhesus monkey, Macaca mulatta (Kawakami et al. 2002), whereas its expression was suppressed by steroids in the rat (Besecke et al. 1996, Leal et al. 2002).

The increased expression of follistatin but not activin $\beta_{\mathrm{B}}$ in response to steroid treatments suggests that it is likely follistatin that serves as a regulatory point of the activinfollistatin system in the pituitary. Although activin $\beta_{\mathrm{B}}$ level remains rather constant, the activities of activin are expected to be fine-tuned by the local level of follistatin in the pituitary. In support of this hypothesis is the in vivo evidence that similar to $\mathrm{FSH} \beta$ and $\mathrm{LH} \beta$, follistatin in the female goldfish pituitary exhibited significant changes in expression during the annual reproductive cycle whereas activin $\beta_{\mathrm{B}}$ showed no evident trend of variation. Although it is difficult to assess the importance of follistatin variation in the annual expression profiles of gonadotropins (FSH and $\mathrm{LH}$ ) at this moment because of the multifactorial nature of $\mathrm{FSH}$ and $\mathrm{LH}$ regulation, this result at least lends further weight to the hypothesis that follistatin in the pituitary may represent a critical regulatory point.

Both testosterone and $\mathrm{E}_{2}$ stimulated $\mathrm{LH} \beta$ expression but lacked effect on FSH $\beta$ expression in the present study. In the goldfish, previous studies using incubated pituitary fragments demonstrated stimulatory effects of testosterone and $E_{2}$ on the expression of both FSH $\beta$ and $\mathrm{LH} \beta$; however, FSH $\beta$ appeared to be less responsive to $\mathrm{E}_{2}$ treatment than $\mathrm{LH} \beta$ (Huggard et al. 1996, Habibi \& Huggard 1998, Huggard-Nelson et al. 2002). The in vitro effect of $\mathrm{E}_{2}$ on gonadotropin subunit expression, especially that of FSH $\beta$, seemed to be dependent on the stage of sexual maturity. $E_{2}$ significantly stimulated FSH $\beta$ expression in cultured pituitary fragments from early but not late recrudescent (vitellogenic) fish (Huggard-Nelson et al. 2002). This stage dependence could also be the reason for the lack of effects of steroids on FSH $\beta$ in the present study because we performed the experiments in February, when the goldfish in Southern China was near the peak spawning period. Indeed, in a previous unpublished study using slot blot hybridization, we did observe significant stimulatory effects of testosterone and $\mathrm{E}_{2}$ on both $\mathrm{FSH} \beta$ and $\mathrm{LH} \beta$ expression in cultured pituitary cells from sexually regressed goldfish (Yuen \& Ge unpublished data). In contrast to the variable response of FSH $\beta$ to steroids, both testosterone and $\mathrm{E}_{2}$ consistently stimulated goldfish LH $\beta$ expression in the present as well as our previous unpublished studies. Although these stimulatory effects could be due to direct actions of these steroids on LH cells, the increase might also be linked to the increased expression of follistatin, which could in turn reduce the inhibitory effect of activin on LH $\beta$ expression. The same speculation does not seem to be applicable to FSH $\beta$, whose expression would be expected to decrease in response to an increased follistatin expression. In mammals, the expression level of FSH $\beta$ has been reported to correlate well with that of pituitary follistatin (Bilezikjian et al. 1996, Kawakami et al. 2002, Leal et al. 2002). One possibility is that goldfish FSH $\beta$ 
may be subject to dual controls by both the intra-pituitary activin-follistatin system and gonadal steroids, and the relatively stable FSH $\beta$ expression in response to steroidal treatments may reflect the net effect of reduced activin stimulation due to the increased follistatin and an increased steroidal stimulation. What is intriguing is that in addition to activin, follistatin has also been reported to bind some members of the bone morphogenetic protein (BMP) family such as BMP-4 and BMP-7 (Iemura et al. 1998), and some BMP members such as BMP-6 and BMP-7 have also been shown to exert a paracrine effect in the pituitary of mammals to regulate gonadotropin expression (Huang et al. 2001). How these BMP ligands fit into the activin-follistatin system in the goldfish pituitary remains to be elucidated.

To summarize, a full-length cDNA for goldfish follistatin was cloned and its expression demonstrated in the pituitary. Further experiments showed that in addition to the differential effects on the expression of goldfish FSH $\beta$ and LH $\beta$, activin also stimulated the expression of its binding protein follistatin within the pituitary, which may represent a local closed-loop negative feedback mechanism to modulate the activities of activin. This mechanism seems to be conserved across vertebrates, suggesting physiological importance of the intra-pituitary activin-follistatin system in controlling pituitary hormone biosynthesis and secretion. Furthermore, the expression of follistatin but not activin itself was regulated by sex steroids, suggesting that it is likely follistatin that serves as the point of the system that is subject to the endocrine or neuroendocrine regulation (Fig. 8). This idea is further supported by the in vivo evidence that the expression of follistatin in the pituitary varied significantly, similar to that of FSH $\beta, \mathrm{LH} \beta$, and $\mathrm{GH}$, whereas activin $\beta_{\mathrm{B}}$ expression remained rather constant during the annual reproductive cycle.

\section{Acknowledgements}

The work was substantially supported by grants (CUHK4150/01M, CUHK4258/02M, CUHK4422/04M, and CUHK4578/05M) from the Research Grants Council of the Hong Kong Special Administrative Region to W G. The authors declare that there is no conflict of interest that would prejudice the impartiality of this scientific work.

\section{References}

Ando H \& Urano A 2005 Molecular regulation of gonadotropin secretion by gonadotropin-releasing hormone in salmonid fishes. Zoological Science $\mathbf{2 2}$ 379-389.

Attardi B, Marshall GR, Zorub DS, Winters SJ, Miklos J \& Plant TM 1992 Effects of orchidectomy on gonadotropin and inhibin subunit messenger ribonucleic acids in the pituitary of the rhesus monkey (Macaca mulatta). Endocrinology 130 1238-1244.

Bauer H, Meier A, Hild M, Stachel S, Economides A, Hazelett D, Harland RM \& Hammerschmidt M 1998 Follistatin and noggin are excluded from the zebrafish organizer. Developmental Biology 204 488-507.
Besecke LM, Guendner MJ, Schneyer AL, Bauer-Dantoin AC, Jameson JL \& Weiss J 1996 Gonadotropin-releasing hormone regulates follicle-stimulating hormone- $\beta$ gene expression through an activin/follistatin autocrine or paracrine loop. Endocrinology 137 3667-3673.

Bilezikjian LM, Corrigan AZ, Vaughan JM \& Vale WM 1993 Activin-A regulates follistatin secretion from cultured rat anterior pituitary cells. Endocrinology 133 2554-2560.

Bilezikjian LM, Corrigan AZ, Blount AL \& Vale WW 1996 Pituitary follistatin and inhibin subunit messenger ribonucleic acid levels are differentially regulated by local and hormonal factors. Endocrinology 137 4277-4284.

Bilezikjian LM, Blount AL, Leal AM, Donaldson CJ, Fischer WH \& Vale WW 2004 Autocrine/paracrine regulation of pituitary function by activin, inhibin and follistatin. Molecular and Cellular Endocrinology 225 29-36.

Burger LL, Haisenleder DJ, Dalkin AC \& Marshall JC 2004 Regulation of gonadotropin subunit gene transcription. Journal of Molecular Endocrinology 33 559-584

Connolly DJ, Patel K, Seleiro EA, Wilkinson DG \& Cooke J 1995 Cloning, sequencing, and expressional analysis of the chick homologue of follistatin. Developmental Genetics 17 65-77.

Corrigan AZ, Bilezikjian LM, Carroll RS, Bald LN, Schmelzer CH, Fendly BM, Mason AJ, Chin WW, Schwall RH \& Vale W 1991 Evidence for an autocrine role of activin B within rat anterior pituitary cultures. Endocrinology 128 16821684.

Dalkin AC, Haisenleder DJ, Yasin M, Gilrain JT \& Marshall JC 1996 Pituitary activin receptor subtypes and follistatin gene expression in female rats: differential regulation by activin and follistatin. Endocrinology 137 548-554.

DePaolo LV, Bicsak TA, Erickson GF, Shimasaki S \& Ling N 1991 Follistatin and activin: a potential intrinsic regulatory system within diverse tissues. Proceedings of the Society for Experimental Biology and Medicine 198 500-512.

DePaolo LV, Bald LN \& Fendly BM 1992 Passive immunoneutralization with a monoclonal antibody reveals a role for endogenous activin-B in mediating FSH hypersecretion during estrus and following ovariectomy of hypophysectomized, pituitary-grafted rats. Endocrinology 130 1741-1743.

Dickey JT \& Swanson P 1998 Effects of sex steroids on gonadotropin (FSH and LH) regulation in coho salmon (Oncorhynchus kisutch). Journal of Molecular Endocrinology 21 291-306.

Esch FS, Shimasaki S, Mercado M, Cooksey K, Ling N, Ying S, Ueno N \& Guillemin R 1987 Structural characterization of follistatin: a novel folliclestimulating hormone release-inhibiting polypeptide from the gonad. Molecular Endocrinology 1 849-855.

Eto Y, Tsuji T, Takezawa M, Takano S, Yokogawa Y \& Shibai H 1987 Purification and characterization of erythroid differentiation factor (EDF) isolated from human leukemia cell line THP-1. Biochemical and Biophysical Research Communications 142 1095-1103.

Farnworth PG, Thean E, Robertson DM \& Schwartz J 1995 Ovine anterior pituitary production of follistatin in vitro. Endocrinology 136 4397-4406.

Ge W, Miura T, Kobayashi H, Peter RE \& Nagahama Y 1997 Cloning of cDNA for goldfish activin $\beta B$ subunit, and the expression of its mRNA in gonadal and non-gonadal tissues. Journal of Molecular Endocrinology 19 37-45.

Gharib SD, Wierman ME, Badger TM \& Chin WW 1987 Sex steroid hormone regulation of follicle-stimulating hormone subunit messenger ribonucleic acid (mRNA) levels in the rat. Journal of Clinical Investigation $\mathbf{8 0}$ 294-299.

Gharib SD, Wierman ME, Shupnik MA \& Chin WW 1990 Molecular biology of the pituitary gonadotropins. Endocrine Reviews 11 177-199.

Gospodarowicz D \& Lau K 1989 Pituitary follicular cells secrete both vascular endothelial growth factor and follistatin. Biochemical and Biophysical Research Communications 165 292-298.

Habibi HR \& Huggard DL 1998 Testosterone regulation of gonadotropin production in goldfish. Comparative Biochemistry and Physiology. Part C, Pharmacology, Toxicology and Endocrinology 119 339-344.

Halvorson LM, Weiss J, Bauer-Dantoin AC \& Jameson JL 1994 Dynamic regulation of pituitary follistatin messenger ribonucleic acids during the rat estrous cycle. Endocrinology 134 1247-1253.

Huang HJ, Wu JC, Su P, Zhirnov O \& Miller WL 2001 A novel role for bone morphogenetic proteins in the synthesis of follicle-stimulating hormone. Endocrinology 142 2275-2283. 
Huggard D, Khakoo Z, Kassam G, Mahmoud SS \& Habibi HR 1996 Effect of testosterone on maturational gonadotropin subunit messenger ribonucleic acid levels in the goldfish pituitary. Biology of Reproduction $\mathbf{5 4}$ 1184-1191.

Huggard-Nelson DL, Nathwani PS, Kermouni A \& Habibi HR 2002 Molecular characterization of LH- $\beta$ and FSH- $\beta$ subunits and their regulation by estrogen in the goldfish pituitary. Molecular and Cellular Endocrinology 188 171-193.

Hull KL \& Harvey S 2002 GH as a co-gonadotropin: the relevance of correlative changes in GH secretion and reproductive state. Journal of Endocrinology 172 1-19.

Iemura SI, Yamamoto TS, Takagi C, Uchiyama H, Natsume T, Shimasaki S, Sugino H \& Ueno N 1998 Direct binding of follistatin to a complex of bone-morphogenetic protein and its receptor inhibits ventral and epidermal cell fates in early Xenopus embryo. PNAS 95 9337-9342.

Inouye S, Guo Y, DePaolo L, Shimonaka M, Ling N \& Shimasaki S 1991 Recombinant expression of human follistatin with 315 and 288 amino acids: chemical and biological comparison with native porcine follistatin. Endocrinology 129 815-822.

Inouye S, Ling N \& Shimasaki S 1992 Localization of the heparin binding site of follistatin. Molecular and Cellular Endocrinology 90 1-6.

Kaiser UB \& Chin WW 1993 Regulation of follistatin messenger ribonucleic acid levels in the rat pituitary. Journal of Clinical Investigation 91 2523-2531.

Kawakami S, Fujii Y, Okada Y \& Winters SJ 2002 Paracrine regulation of FSH by follistatin in folliculostellate cell-enriched primate pituitary cell cultures. Endocrinology 143 2250-2258.

Kirk SE, Dalkin AC, Yasin M, Haisenleder DJ \& Marshall JC 1994 Gonadotropin-releasing hormone pulse frequency regulates expression of pituitary follistatin messenger ribonucleic acid: a mechanism for differential gonadotrope function. Endocrinology 135 876-880.

Kobayashi M, Aida K \& Hanyu I 1987 Hormone changes during ovulation and effects of steroid hormones on plasma gonadotropin levels and ovulation in goldfish. General and Comparative Endocrinology 67 24-32.

Kobayashi M, Aida K \& Hanyu I 1989 Induction of gonadotropin surge by steroid hormone implantation in ovariectomized and sexually regressed female goldfish. General and Comparative Endocrinology 73 469-476.

Kogawa K, Ogawa K, Hayashi Y, Nakamura T, Titani K \& Sugino H 1991 Immunohistochemical localization of follistatin in rat tissues. Endocrinologia Japonica 38 383-391.

Kozak M 1984 Compilation and analysis of sequences upstream from the translational start site in eukaryotic mRNAs. Nucleic Acids Research $\mathbf{1 2}$ 857-872.

Lau MT \& Ge W 2005 Cloning of Smad2, Smad3, Smad4, and Smad7 from the goldfish pituitary and evidence for their involvement in activin regulation of goldfish FSH $\beta$ promoter activity. General and Comparative Endocrinology 141 22-38.

Leal AM, Takabe K, Wang L, Donaldson CJ, MacConell LA, Bilezikjian LM, Verma IM \& Vale W 2002 Effect of adenovirus-mediated overexpression of follistatin and extracellular domain of activin receptor type II on gonadotropin secretion in vitro and in vivo. Endocrinology 143 964-969.

Ling N, Ying SY, Ueno N, Shimasaki S, Esch F, Hotta M \& Guillemin R 1986 Pituitary FSH is released by a heterodimer of the $\beta$-subunits from the two forms of inhibin. Nature 321 779-782.

Machida H, Ogawa K, Funaba M, Mizutani T \& Tsujimoto M 2000 mRNA expression of type I and type II receptors for activin, transforming growth factor- $\beta$, and bone morphogenetic protein in the murine erythroleukemic cell line, F5-5.fl. European Journal of Endocrinology 143 705-710.

Meunier H, Rivier C, Evans RM \& Vale W 1988 Gonadal and extragonadal expression of inhibin $\alpha, \beta \mathrm{A}$, and $\beta \mathrm{B}$ subunits in various tissues predicts diverse functions. PNAS 85 247-251.

Michel U, Albiston A \& Findlay JK 1990 Rat follistatin: gonadal and extragonadal expression and evidence for alternative splicing. Biochemical and Biophysical Research Communications 173 401-407.

Peter RE, Chang JP, Nahorniak CS, Omeljaniuk RJ, Sokolowska M, Shih SH \& Billard R 1986 Interactions of catecholamines and GnRH in regulation of gonadotropin secretion in teleost fish. Recent Progress in Hormone Research 42 513-548.
Roberts V, Meunier H, Vaughan J, Rivier J, Rivier C, Vale W \& Sawchenko P 1989 Production and regulation of inhibin subunits in pituitary gonadotropes. Endocrinology 124 552-554.

Robertson DM, Klein R, de Vos FL, McLachlan RI, Wettenhall RE, Hearn MT, Burger HG \& de Kretser DM 1987 The isolation of polypeptides with FSH suppressing activity from bovine follicular fluid which are structurally different to inhibin. Biochemical and Biophysical Research Communications 149 744-749.

Schwall RH \& Lai C 1991 Erythroid differentiation bioassays for activin. Methods in Enzymology 198 340-346.

Shimasaki S, Koga M, Esch F, Cooksey K, Mercado M, Koba A, Ueno N, Ying SY, Ling N \& Guillemin R 1988a Primary structure of the human follistatin precursor and its genomic organization. PNAS $\mathbf{8 5}$ $4218-4222$.

Shimasaki S, Koga M, Esch F, Mercado M, Cooksey K, Koba A \& Ling N $1988 b$ Porcine follistatin gene structure supports two forms of mature follistatin produced by alternative splicing. Biochemical and Biophysical Research Communications 152 717-723.

Sohn YC, Yoshiura Y, Kobayashi M \& Aida K 1999 Seasonal changes in mRNA levels of gonadotropin and thyrotropin subunits in the goldfish, Carassius auratus. General and Comparative Endocrinology 113 436-444.

Sumitomo S, Inouye S, Liu XJ, Ling N \& Shimasaki S 1995 The heparin binding site of follistatin is involved in its interaction with activin. Biochemical and Biophysical Research Communications 208 1-9.

Swanson P, Dickey JT \& Campbell B 2003 Biochemistry and physiology of fish gonadotropins. Fish Physiology and Biochemistry 28 53-59.

Tashiro K, Yamada R, Asano M, Hashimoto M, Muramatsu M \& Shiokawa K 1991 Expression of mRNA for activin-binding protein (follistatin) during early embryonic development of Xenopus laevis. Biochemical and Biophysical Research Communications 174 1022-1027.

Ueno N, Ling N, Ying SY, Esch F, Shimasaki S \& Guillemin R 1987 Isolation and partial characterization of follistatin: a single-chain $\mathrm{Mr} 35000$ monomeric protein that inhibits the release of follicle-stimulating hormone. PNAS 84 8282-8286.

Vale W, Rivier J, Vaughan J, McClintock R, Corrigan A, Woo W, Karr D \& Spiess J 1986 Purification and characterization of an FSH releasing protein from porcine ovarian follicular fluid. Nature 321 776-779.

Walmsley AR \& Hooper NM 2003 Glycosylation efficiency of Asn-Xaa-Thr sequons is independent of distance from the C-terminus in membrane dipeptidase. Glycobiology 13 641-646.

Welt C, Sidis Y, Keutmann H \& Schneyer A 2002 Activins, inhibins, and follistatins: from endocrinology to signaling. A paradigm for the new millennium. Experimental Biology and Medicine 227 724-752.

Weltzien FA, Andersson E, Andersen O, Shalchian-Tabrizi K \& Norberg B 2004 The brain-pituitary-gonad axis in male teleosts, with special emphasis on flatfish (Pleuronectiformes). Comparative Biochemistry and Physiology. Part A, Molecular and Integrative Physiology 137 447-477.

Yam KM, Yoshiura Y, Kobayashi M \& Ge W 1999a Recombinant goldfish activin B stimulates gonadotropin-I $\beta$ but inhibits gonadotropin-II $\beta$ expression in the goldfish, Carassius auratus. General and Comparative Endocrinology 116 81-89.

Yam KM, Yu KL \& Ge W 19996 Cloning and characterization of goldfish activin $\beta$ A subunit. Molecular and Cellular Endocrinology 154 45-54.

Yuen CW \& Ge W 2004 Follistatin suppresses FSH $\beta$ but increases LH $\beta$ expression in the goldfish - evidence for an activin-mediated autocrine/paracrine system in fish pituitary. General and Comparative Endocrinology 135 108-115.

Received in final form 7 September 2007

Accepted 24 September 2007

Made available online as an Accepted Preprint 25 September 2007 